\title{
Harvest Time and Fertility Effects on Yield and Quality of Forage from Alfalfa, Hybrid Bromegrass and Their Mixture
}

\author{
Al Foster ${ }^{*}$, Bill Biligetu ${ }^{2}$, Sukhdev S. Malhi' ${ }^{3}$ Kabal S. Gill' ${ }^{4}$, Brett Mollison ${ }^{5}$, Darwin Leach $^{5}$ \\ ${ }^{1}$ Saskatchewan Ministry of Agriculture, Tisdale, Saskatchewan, Canada \\ ${ }^{2}$ University of Saskatchewan, Saskatoon, Saskatchewan, Canada \\ ${ }^{3}$ Department of Renewable Resources, University of Alberta, Edmonton, Alberta, Canada \\ ${ }^{4}$ SARDA Ag Research, Falher, Alberta, Canada \\ ${ }^{5}$ Agriculture and Agri-Food Canada, Research Farm, Melfort, Saskatchewan, Canada \\ Email: *Al.Foster@gov.sask.ca
}

How to cite this paper: Foster, A., Biligetu, B., Malhi, S.S., Gill, K.S., Mollison, B. and Leach, D. (2021) Harvest Time and Fertility Effects on Yield and Quality of Forage from Alfalfa, Hybrid Bromegrass and Their Mixture. Agricultural Sciences, 12, 325-338. https://doi.org/10.4236/as.2021.124021

Received: February 25, 2021

Accepted: March 28, 2021

Published: April 1, 2021

Copyright (c) 2021 by author(s) and Scientific Research Publishing Inc. This work is licensed under the Creative Commons Attribution International License (CC BY 4.0)

http://creativecommons.org/licenses/by/4.0/

\begin{abstract}
A field experiment with 24 treatments consisting of three perennial forage crops [alfalfa (Medicago sativa L. cv. AC Longview), hybrid bromegrass (Bromus riparius Rehm \& Bromus inermis Leyss. cv. AC Success) and their mixture], four Cut 1 dates (approximately June 20, July 10, July 30 or August 20), and two fertilizer levels (unfertilized and fertilized) was established in late May 2014, on a Black Chernozem [Udic Boroll] silty clay soil. Forage dry matter yield [DMY], and concentration $\left(\mathrm{g} \cdot \mathrm{kg}^{-1} \mathrm{DM}\right)$ of crude protein [CP], total digestible nutrients [TDN] and acid detergent fiber [ADF] data were collected over 3 years from 2015 to 2017. The fertilizer treatments were imposed in 2016 and 2017. Forage crops were initially cut at four Cut 1 dates, and again cut [Cut 2] in autumn (September 2 in 2015, November 7 in 2016 and October 5 in 2017). For all three forage crops, forage DMY usually increased when Cut 1 was delayed. Delaying Cut 1 reduced forage DMY for Cut 2. Total DMY (Cut $1+$ Cut 2) for all three forage crops was highest from the combination of July 10 and late Autumn cuts. Alfalfa-bromegrass mixture produced higher DMY than bromegrass or alfalfa alone. Fertilizer application resulted in a significant increase in Cut 1 and total DMY for bromegrass. The $\mathrm{CP}$ concentration in Cut 1 forage usually declined as the forage crops matured. The CP concentration was highest for alfalfa, followed by alfalfa-bromegrass mixture, and much lower for bromegrass. There was little or no effect of forage crop maturity on the TDN and ADF concentrations in forage. The TDN concentration was higher and ADF concentration was lower in forage from alfalfa or alfalfa-bromegrass mixture than bromegrass. Fertilizer application significantly increased CP concentration for alfalfa-bromegrass mixture. De-
\end{abstract}


laying harvesting for Cut 1 increased ADF yield and TDN yield until Late July, but CP yield generally decreased with crop maturity. The ADF yield and TDN yield were higher for alfalfa-bromegrass mixture than bromegrass or alfalfa alone, and CP yield was similar for alfalfa and alfalfa-bromegrass mixture but considerably higher than bromegrass. Fertilizer application increased $\mathrm{CP}$ yield and ADF yield for bromegrass and alfalfa-bromegrass mixture, and TDN yield only for bromegrass. In conclusion, total DMY (Cut $1+$ Cut 2) was highest for a combination of Early July and Autumn cuts. Forage yield was highest for alfalfa-bromegrass mixture, followed by alfalfa and lowest for bromegrass. The CP and TDN concentrations were higher, and ADF concentrations were lower in forage from alfalfa or alfalfa-bromegrass mixture than bromegrass.

\section{Keywords}

Alfalfa, Bromegrass, Cutting Stage, Fertility, Forage, Harvest Time, Hay, Mixture, Quality, Yield

\section{Introduction}

Decisions on when to cut perennial forage crops for hay are based on consideration of both quantity and quality of forage. Protein and energy contents (or concentrations) of hay generally decline and dry matter yield (DMY) increase with advancing plant maturity [1] [2] [3] [4]. Recommendations for the optimum combination of forage yield and quality have historically been to cut alfalfa at the $10 \%$ bloom stage and grasses at anthesis [5] [6]. Yu [7] in a study in Western Canada found the best combination of protein and energy for hay was when alfalfa was cut at the late bud stage and timothy was cut at the pre-bloom head stage. More recently, alfalfa height has been used as a predictor of NDF values for alfalfa, alfalfa-grass mixture and grass stands. Recent research by Cornell University on alfalfa-grass mixtures suggests cutting alfalfa stands when alfalfa is 28 inches tall and 50:50 alfalfa-grass stands when nearby alfalfa is 22 inches tall [8].

Producers must also work around inclement weather to manage significant acres with limited equipment and manpower to make the final decision on when to harvest. As a result, in rain fed environments the haying season often takes weeks or months before completion and forage quality often suffers. Producers know that forage cut in late July or early August in northeast Saskatchewan will have lower protein and energy content than hay cut in late June or early July [2] [9]. However little information is available to producers on how a combination of factors such as fertility, initial harvest stage and crop type can influence hay yield and quality under the same growing and environmental conditions. Having more information on how hay quality and yield are affected by cutting date and fertility would help producers in determining appropriate harvest dates for Cut 1 
harvest dates for optimum hay in terms of protein and energy contents as well as DMY [10]. It will also assist them in determining if their current hay cutting schedule could be modified to better suit their livestock winter feeding requirements in terms of protein and energy intake.

The objective of this study was to determine the effects of Cut 1 date on forage (hay) yield and quality of fertilized and unfertilized hybrid bromegrass, alfalfa and a mixture of the two crops during the first three years of production in the Parkland region of Saskatchewan, Canada.

\section{Materials and Methods}

In the 3-year (from 2015 to 2017) field experiment, forage stands were established during summer 2014 on a field previously cropped to annual grains and oilseeds at the Agriculture and Agri-Food Canada (AAFC) Research Farm, Melfort, Saskatchewan $\left(52^{\circ} 44^{\prime} \mathrm{N} 104^{\circ} 47^{\prime} \mathrm{W}\right)$, on a thick Black Chernozem (Udic Boroll) silty clay soil, with $6.4 \mathrm{pH}$ and $8.2 \%$ organic matter. Soil tests $(0-15 \mathrm{~cm}$ depth) at the start of this experiment indicated nutrient levels of $80 \mathrm{~kg}$ nitrate- $\mathrm{N}$ $\mathrm{ha}^{-1}, 65 \mathrm{~kg}$ available $\mathrm{P} \mathrm{ha}{ }^{-1}, 670 \mathrm{~kg}$ exchangeable $\mathrm{K} \mathrm{ha}^{-1}$ and $17 \mathrm{~kg}$ sulphate-S $\mathrm{ha}^{-1}$.

There were 24 treatments consisting of three forage crops, four harvest dates and two fertilizer levels, arranged in a randomized complete block design (RCBD) with four replications (with total of 96 plots). Individual plots were 1.2 $\mathrm{m} \times 6 \mathrm{~m}$ in size, with four rows spaced $30 \mathrm{~cm}$ apart in each plot.

The alfalfa (Medicago sativa L. cv. AC Longview), hybrid bromegrass (Bromus riparius Rehm \& Bromus inermis Leyss. cv. AC Success) and their mixture were seeded ( $1 \mathrm{~cm}$ deep) in late May 2014. The seeding rate was $9 \mathrm{~kg} \cdot \mathrm{ha}^{-1}$ for pure alfalfa, $9 \mathrm{~kg} \cdot \mathrm{ha}^{-1}$ for pure bromegrass, and $3.4 \mathrm{~kg}$ alfalfa ha $\mathrm{ha}^{-1}+5.6 \mathrm{~kg}$ bromegrass $\mathrm{ha}^{-1}$ for alfalfa-bromegrass mixture. The emergence of all forage crop types was excellent in all experimental plots. The four cutting dates for Cut 1 in 2015, 2016 and 2017 were approximately June 20 (Late June), July 10 (Early July), July 30 (Late July) or August 20 (Late August), based on the early bud, 25\% bloom, full flower (100\% bloom), and seed set stages of alfalfa, respectively. In addition to Cut 1, all crops were again cut (Cut 2) in autumn (September 2 in 2015, November 7 in 2016 and October 5 in 2017). The two fertilizer application levels, applied only in 2016 and 2017, were unfertilized or fertilized at $67 \mathrm{~N}+11.2 \mathrm{P}_{2} \mathrm{O}_{5}$ $+0 \mathrm{~S} \mathrm{~kg} \cdot \mathrm{ha}^{-1}$ for bromegrass, $33.5 \mathrm{~N}+22.4 \mathrm{P}_{2} \mathrm{O}_{5}+5.6 \mathrm{~S} \mathrm{~kg} \cdot \mathrm{ha}^{-1}$ for alfalfa-grass mixture, and $0 \mathrm{~N}+44.8 \mathrm{P}_{2} \mathrm{O}_{5}+11.2 \mathrm{~S} \mathrm{~kg} \cdot \mathrm{ha}^{-1}$ for alfalfa treatments. Fertilizers were broadcast in the spring each year. No herbicide was applied during the course of the study.

For each harvest time, all four crop rows were cut about $5 \mathrm{~cm}$ above the soil surface for hay, using a mechanical harvester (Haldrup forage harvester, Haldrup GmbH, Justus-von-Liebig Str. Ilshofen, Germany D-74532). Fresh mass of the harvested material was measured. Sub-samples of about $200 \mathrm{~g}$ fresh mass for each plot were weighed and dried in a forced air oven at $60^{\circ} \mathrm{C}$ for dry matter 
yield (DMY) and quality.

Forage samples from each Cut 1 harvest date were collected for forage quality. Dry sub samples were combined from replicates one + two, and three + four, finely ground, and then sent for quality analysis, to the Central Testing Lab in Winnipeg (Unit 9 - 851 Lagimodiere Blvd Winnipeg, Manitoba Canada). Samples were analyzed for total $\mathrm{N}$ [11], to calculate crude protein [CP], as total $\mathrm{N}$ concentration $\times 6.25$. Acid detergent fiber $[\mathrm{ADF}]$ was determined by the lignin in animal feed method [12]. Neutral detergent fiber [NDF] was determined after digestion of samples in neutral detergent solution with Labconco digestion unit ([13]; Labconco, Kansas City, Mo). Total digestible nutrient [TDN] was calculated from the ADF and NDF. The yield $\left(\mathrm{kg} \cdot \mathrm{ha}^{-1}\right)$ of each nutrient (ADF, CP or TDN) in forage was calculated as DMY $\left(\mathrm{kg} \cdot \mathrm{ha}^{-1}\right)$ of forage multiplied by concentration $\left(\mathrm{g} \cdot \mathrm{kg}^{-1}\right)$ of the nutrient in forage divided by 1000 .

Growing season (May to September) precipitation and temperature data were collected from the AAFC Melfort Research Farm weather station, by Environment Canada (Table 1). In 2015, the growing season precipitation was much below normal for May, much higher than normal for September, near normal for June and August, and almost twice the normal for July. In 2016, the growing season precipitation was much below normal for May, much higher than normal for August, only slightly higher than normal for September, near normal for June, and about 1.7 times than normal for July. In 2017, precipitation was near normal for May and June while it was much below normal in July, August and September. Total of growing season precipitation was above long-term average in 2015 and 2016, while it was lower than long-term average in 2017. Growing season monthly mean temperatures were slightly higher than normal in all the three years of this study.

Data on forage DMY (Cut 1, Cut 2, and total DMY), and Cut 1 nutritive values ( $\mathrm{CP}, \mathrm{ADF}$ and TDN concentrations; $\mathrm{CP}, \mathrm{ADF}$, and TDN yield) were analyzed

Table 1. Total monthly precipitation and mean monthly temperatures in May, June, July, August and September (growing season), and total annual precipitation and mean annual temperatures for 2015, 2016 and 2017 at Melfort, Saskatchewan, Canada. Their long-term values are also presented.

\begin{tabular}{ccccccccc}
\hline Month & \multicolumn{3}{c}{ Total Precipitation $(\mathrm{mm})$} & \multicolumn{3}{c}{ Mean Temperature $\left({ }^{\circ} \mathrm{C}\right)$} \\
\hline & 2015 & 2016 & 2017 & Long-term & 2015 & 2016 & 2017 & Long-term \\
\hline May & 7.1 & 16.8 & 46.4 & 42.9 & 11.2 & 15.4 & 11.6 & 10.7 \\
June & 54.8 & 53.2 & 44.1 & 54.3 & 17.0 & 17.2 & 17.7 & 15.9 \\
July & 149.8 & 128.7 & 33.3 & 76.7 & 17.7 & 19.2 & 19.1 & 17.5 \\
August & 57.4 & 80.8 & 3.1 & 52.4 & 17.3 & 16.3 & 18.2 & 16.8 \\
September & 70.0 & 41.3 & 13.2 & 38.7 & 12.9 & 13.7 & 15.0 & 10.8 \\
Total/mean & 339.1 & 320.8 & 140.1 & 265.0 & 15.2 & 16.4 & 16.3 & 14.3 \\
Total/mean annual & 459.8 & 458.0 & 263.5 & 395.8 & 3.3 & 3.0 & 2.5 & 1.3 \\
\hline
\end{tabular}


considering factorial set of treatments arranged in a randomized complete block design (RCBD) using Proc Mixed Model procedure of SAS 9.4 [14]. In Proc Mixed Model, the harvest management (4 Cut 1 times), forage crop types (bromegrass, alfalfa, and brome-alfalfa mixture), fertilizer (unfertilized and fertilized) and their interactions were considered as fixed effects, while the replication, year and replication $\times$ harvest management were set as random effects. Statistical significance was declared at $\mathrm{P}=0.05$, and means were separated using Least Square Means comparison.

\section{Results}

For the measured parameters, almost all the main effects of forage crop, fertility and Cut 1 date; and the interactions of forage crop $\times$ fertility, and forage crop $\times$ Cut 1 date were significant; while almost all the fertility $\times$ Cut 1 , and forage crop $\times$ fertility $\times$ Cut 1 date interactions were not significant. Thus, the means for forage crop $\times$ fertility interaction, forage crop $\times$ Cut 1 date interaction, forage crop, Cut 1 date and fertility only are presented.

\section{Dry matter yield (DMY)}

The interaction effects of forage crop $\times$ fertility were significant for Cut 1 and total DMY, and of forage crop $\times$ Cut 1 date were significant for both cuts and total DMY, but the fertility $\times$ Cut 1 date and forage crop $\times$ fertility $\times$ Cut 1 date were not significant (Table 2). Significant fertility effect was observed for Cut 1 DMY of bromegrass, and for total DMY of bromegrass and alfalfa-bromegrass mixture. With delay in Cut 1, the DMY for Cut 1 increased up to Late July for alfalfa and alfalfa-bromegrass mixture and up to Late August for bromegrass, and total DMY increased up to Early July for all three forage crop types, while it always decreased for Cut 2 .

Table 2. The dry matter yield (DMY, $\mathrm{kg} \cdot \mathrm{ha}^{-1}$-average of 2015, 2016, and 2017) of alfalfa, bromegrass, and alfalfa-bromegrass mixture forage, for the Cut 1, Cut 2 and total with and without fertilizer at Melfort, Saskatchewan, Canada.

\begin{tabular}{ccccc}
\hline \multicolumn{5}{c}{ DMY $\left({\left.\mathrm{kg} \cdot h \mathrm{~h}^{-1}\right)}^{-1}\right.$} \\
\hline & \multicolumn{4}{c}{ Forage Crop $\times$ Fertility Interaction Effects } \\
\hline Crop & Fertility & Cut 1 & Cut 2 & Total \\
\hline Alfalfa & No & $5454 \mathrm{~b}^{\mathrm{a}}$ & 2597 & $8051 \mathrm{c}$ \\
& Yes & $5529 \mathrm{~b}$ & 2628 & $8156 \mathrm{c}$ \\
Bromegrass & No & $5505 \mathrm{~b}$ & 1237 & $6742 \mathrm{~d}$ \\
& Yes & $6921 \mathrm{a}$ & 1373 & $8294 \mathrm{bc}$ \\
Alfalfa + Bromegrass & No & $6556 \mathrm{a}$ & 2470 & $9026 \mathrm{ab}$ \\
& Yes & $6876 \mathrm{a}$ & 2550 & $9426 \mathrm{a}$ \\
P values & & 0.0002 & 0.797 & $<0.0001$ \\
SEM & & 329 & 598 & 440 \\
\hline
\end{tabular}




\section{Continued}

\begin{tabular}{|c|c|c|c|c|}
\hline \multicolumn{5}{|c|}{ Forage Crop $\times$ Cut 1 Date Interaction Effects } \\
\hline & Time of first harvest & Cut 1 & Cut 2 & Total \\
\hline \multirow{4}{*}{ Alfalfa } & Late June & $4030 \mathrm{~g}$ & $3607 a$ & $7637 \mathrm{ef}$ \\
\hline & Early July & 5928 cde & $3659 a$ & $9588 \mathrm{~b}$ \\
\hline & Late July & $6272 \mathrm{~cd}$ & $2362 b c$ & $8633 \mathrm{~cd}$ \\
\hline & Late August & $5735 \mathrm{de}$ & $822 \mathrm{e}$ & $6556 \mathrm{~g}$ \\
\hline \multirow[t]{4}{*}{ Bromegrass } & Late June & $4784 \mathrm{f}$ & $2537 b$ & $7321 \mathrm{efg}$ \\
\hline & Early July & $6154 \mathrm{~cd}$ & $1782 \mathrm{~d}$ & 7936de \\
\hline & Late July & $6530 \mathrm{bc}$ & $670 \mathrm{e}$ & $7200 \mathrm{fg}$ \\
\hline & Late August & $7383 a$ & $231 \mathrm{f}$ & $7614 \mathrm{ef}$ \\
\hline \multirow[t]{4}{*}{ Alfalfa + Bromegrass } & Late June & $5374 \mathrm{ef}$ & $3830 \mathrm{a}$ & $9204 \mathrm{bc}$ \\
\hline & Early July & $7060 \mathrm{ab}$ & $3568 \mathrm{a}$ & $10628 \mathrm{a}$ \\
\hline & Late July & $7343 a$ & $2116 \mathrm{~cd}$ & $9460 \mathrm{bc}$ \\
\hline & Late August & $7085 \mathrm{ab}$ & $527 \mathrm{ef}$ & $7612 \mathrm{ef}$ \\
\hline$P$ values & & 0.0443 & $<0.0001$ & $<0.0001$ \\
\hline SEM & & 370 & 603 & 473 \\
\hline \multicolumn{5}{|c|}{ Forage Crop Means } \\
\hline Crop & & Cut 1 & Cut 2 & Total \\
\hline Alfalfa & & $5491 \mathrm{c}$ & $2612 a$ & $8104 b$ \\
\hline Bromegrass & & $6213 b$ & $1305 b$ & $7518 b$ \\
\hline Alfalfa + Bromegrass & & $6716 a$ & $2510 \mathrm{a}$ & $9226 a$ \\
\hline $\mathrm{P}$ values & & 0.0006 & $<0.0001$ & 0.0014 \\
\hline SEM & & 306 & 595 & 422 \\
\hline \multicolumn{5}{|c|}{ Cut 1 Date Means } \\
\hline Cut date & & Cut 1 & Cut 2 & Total \\
\hline Late June & & $4729 b$ & $3325 a$ & $8054 b$ \\
\hline Early July & & $6381 \mathrm{a}$ & $3003 b$ & $9384 a$ \\
\hline Late July & & $6715 a$ & $1716 \mathrm{c}$ & $8431 b$ \\
\hline Late August & & $6734 \mathrm{a}$ & $527 \mathrm{~d}$ & $7261 c$ \\
\hline $\mathrm{P}$ values & & $<0.0001$ & $<0.0001$ & $<0.0001$ \\
\hline SEM & & 308 & 593 & 400 \\
\hline \multicolumn{5}{|c|}{ Fertility Means } \\
\hline Fertility & & Cut 1 & Cut 2 & Total \\
\hline Unfertilized & & $5838 \mathrm{~b}$ & $2101 \mathrm{a}$ & $7939 b$ \\
\hline Fertilized & & $6442 \mathrm{a}$ & $2184 \mathrm{a}$ & $8625 a$ \\
\hline $\mathrm{P}$ values & & $<0.0001$ & 0.1997 & $<0.0001$ \\
\hline SEM & & 291 & 591 & 387 \\
\hline
\end{tabular}

The same lowercase letters within a column for a particular treatment or interaction effect indicate no significant difference between treatments at $\mathrm{P}=0.05$. 
The mean effect of forage crops was significant for the DMY of both cuts and total DMY (Table 2). The DMY sequences were alfalfa-bromegrass mixture > bromegrass $>$ alfalfa for Cut 1 ; alfalfa-bromegrass mixture and alfalfa $>$ bromegrass for Cut 2; and alfalfa-bromegrass mixture > bromegrass and alfalfa for their total DMY.

Like forage crops, the DMY of both cuts and total DMY showed significant effect of Cut 1 dates (Table 2). The Cut 1 DMY from Early July, Late July and Late August was greater than from the Late June. The Cut 2 DMY always declined with delay in Cut 1 date. Total DMY was significantly higher for the Early July and lower for the Late August cut compared to the Late June and Late July Cut 1 dates. The cut 1 DMY and total DMY showed significant increase from the fertilizer application but Cut 2 DMY was not influenced by the fertilizer application (Table 2).

\section{Crude protein (CP) concentration and yield}

The interaction effects of forage crop $\times$ fertility were significant for both the $\mathrm{CP}$ concentration and CP yield (Table 3 and Table 4). Fertilizer application significantly increased the $\mathrm{CP}$ concentration of alfalfa-bromegrass mixture only, and it increased the $\mathrm{CP}$ yield of bromegrass and alfalfa-bromegrass mixture.

Significant interaction effects of forage crop $\times$ Cut 1 date were for both the $\mathrm{CP}$ concentration and CP yield (Table 3 and Table 4). For all the forage crops, there was a trend of significant decline in $\mathrm{CP}$ concentration with the delay in Cut 1 date from Late June until Late July, and with no significant change between the Late July and Late August dates. The CP yield was significantly greater from Early July and lower from Late August than the other two Cut 1 dates of Alfalfa; significantly greater from the Late June and Early July than the two later Cut 1 dates of the bromegrass and alfalfa-bromegrass mixture.

Table 3. Concentration ( $\left.\mathrm{g} \cdot \mathrm{kg}^{-1} \mathrm{DM}\right)$ of crude protein (CP), acid detergent fiber (ADF) and total digestible nutrients (TDN) in alfalfa, bromegrass, and alfalfa-bromegrass mixture forage (average of 2015, 2016 and 2017), harvested at different dates of Cut 1 with and without fertilizer at Melfort, Saskatchewan, Canada.

\begin{tabular}{ccccc}
\hline \multicolumn{5}{c}{ Concentration $\left(\mathrm{g} \cdot \mathrm{kg}^{-1} \mathrm{DM}\right)$} \\
\hline \multicolumn{5}{c}{ Forage Crop $\times$ Fertility Interaction Effects } \\
\hline Crop & Fertility & ADF & CP & TDN \\
\hline Alfalfa & No & $382 \mathrm{a}^{\mathrm{a}}$ & $139 \mathrm{a}$ & $578 \mathrm{a}$ \\
& Yes & $379 \mathrm{a}$ & $138 \mathrm{a}$ & $582 \mathrm{a}$ \\
Bromegrass & No & $389 \mathrm{a}$ & $83 \mathrm{~d}$ & $571 \mathrm{a}$ \\
& Yes & $396 \mathrm{a}$ & $85 \mathrm{~d}$ & $563 \mathrm{a}$ \\
Alfalfa + Bromegrass & No & $376 \mathrm{a}$ & $104 \mathrm{c}$ & $585 \mathrm{a}$ \\
& Yes & $387 \mathrm{a}$ & $125 \mathrm{~b}$ & $573 \mathrm{a}$ \\
P values & & 0.0590 & 0.0104 & 0.0589 \\
SEM & & 5.2 & 4.0 & 5.6 \\
\hline
\end{tabular}




\section{Continued}

\begin{tabular}{|c|c|c|c|c|}
\hline \multicolumn{5}{|c|}{ Forage Crop $\times$ Cut 1 Date Interaction Effects } \\
\hline & Time of first harvest & $\mathrm{ADF}$ & $\mathrm{CP}$ & TDN \\
\hline \multirow[t]{4}{*}{ Alfalfa } & Late June & $369 a$ & $174 \mathrm{a}$ & $592 a$ \\
\hline & Early July & $388 \mathrm{a}$ & $152 b$ & $571 \mathrm{a}$ \\
\hline & Late July & $385 \mathrm{a}$ & $122 \mathrm{~cd}$ & $575 a$ \\
\hline & Late August & $378 \mathrm{a}$ & $107 \mathrm{de}$ & $582 \mathrm{a}$ \\
\hline \multirow[t]{4}{*}{ Bromegrass } & Late June & $395 a$ & $126 c$ & $564 a$ \\
\hline & Early July & $388 \mathrm{a}$ & $103 \mathrm{e}$ & $572 \mathrm{a}$ \\
\hline & Late July & $401 \mathrm{a}$ & $55 f$ & $558 \mathrm{a}$ \\
\hline & Late August & $387 \mathrm{a}$ & $52 \mathrm{f}$ & $573 \mathrm{a}$ \\
\hline \multirow[t]{4}{*}{ Alfalfa + Bromegrass } & Late June & $378 \mathrm{a}$ & $142 \mathrm{~b}$ & $582 \mathrm{a}$ \\
\hline & Early July & $376 \mathrm{a}$ & $121 \mathrm{~cd}$ & $585 \mathrm{a}$ \\
\hline & Late July & $390 \mathrm{a}$ & $95 \mathrm{e}$ & $570 \mathrm{a}$ \\
\hline & Late August & $380 \mathrm{a}$ & $102 \mathrm{e}$ & $580 \mathrm{a}$ \\
\hline$P$ values & & 0.0771 & 0.0128 & 0.0765 \\
\hline SEM & & 6.2 & 5.7 & 6.6 \\
\hline \multicolumn{5}{|c|}{ Forage Crop Means } \\
\hline Crop & & $\mathrm{ADF}$ & $\mathrm{CP}$ & TDN \\
\hline Alfalfa & & $380 \mathrm{~b}$ & $139 \mathrm{a}$ & $580 \mathrm{a}$ \\
\hline Bromegrass & & $393 a$ & $84 c$ & $567 \mathrm{~b}$ \\
\hline Alfalfa + Bromegrass & & $381 b$ & $115 b$ & $579 a$ \\
\hline $\mathrm{P}$ values & & 0.0001 & $<0.0001$ & 0.0001 \\
\hline SEM & & 4.7 & 2.8 & 5.0 \\
\hline \multicolumn{5}{|c|}{ Cut 1 Date Means } \\
\hline Cut date & & $\mathrm{ADF}$ & $\mathrm{CP}$ & TDN \\
\hline Late June & & $381 b$ & $147 \mathrm{a}$ & $579 a$ \\
\hline Early July & & $384 \mathrm{~b}$ & $125 b$ & $576 a$ \\
\hline Late July & & $392 \mathrm{a}$ & $91 \mathrm{c}$ & $568 \mathrm{~b}$ \\
\hline Late August & & $382 \mathrm{~b}$ & $87 \mathrm{c}$ & $578 \mathrm{a}$ \\
\hline $\mathrm{P}$ values & & 0.0135 & $<0.0001$ & 0.0134 \\
\hline SEM & & 4.8 & 3.2 & 5.2 \\
\hline \multicolumn{5}{|c|}{ Fertility Means } \\
\hline Fertility & & $\mathrm{ADF}$ & $\mathrm{CP}$ & TDN \\
\hline Unfertilized & & $382 \mathrm{a}$ & $109 \mathrm{~b}$ & $578 \mathrm{a}$ \\
\hline Fertilized & & $387 \mathrm{a}$ & $116 \mathrm{a}$ & $573 a$ \\
\hline $\mathrm{P}$ values & & 0.0515 & 0.0261 & 0.0516 \\
\hline SEM & & 4.5 & 2.2 & 4.8 \\
\hline
\end{tabular}

The same lowercase letters within a column for a particular treatment or interaction effect indicate no significant difference between treatments at $\mathrm{P}=0.05$. 
Table 4. Yield $\left(\mathrm{kg} \cdot \mathrm{ha}^{-1}\right)$ of crude protein (CP), acid detergent fiber (ADF) and total digestible nutrients (TDN) for alfalfa, bromegrass and alfalfa-bromegrass mixture forage (average of 2015, 2016 and 2017), harvested at different dates of Cut 1 with and without fertilizer at Melfort, Saskatchewan, Canada.

\begin{tabular}{|c|c|c|c|c|c|}
\hline \multicolumn{6}{|c|}{ Yield $\left(\mathrm{kg} \cdot \mathrm{ha}^{-1}\right)$} \\
\hline \multicolumn{6}{|c|}{ Forage Crop $\times$ Fertility Interaction Effects } \\
\hline Crop & Fertility & $\mathrm{ADF}$ & & $\mathrm{CP}$ & TDN \\
\hline \multirow[t]{2}{*}{ Alfalfa } & No & $2304 c^{\mathrm{a}}$ & & $828 \mathrm{a}$ & $3460 \mathrm{~b}$ \\
\hline & Yes & $2308 \mathrm{c}$ & & $836 \mathrm{a}$ & $3537 b$ \\
\hline \multirow[t]{2}{*}{ Bromegrass } & No & 1991d & & $412 \mathrm{~d}$ & $2907 c$ \\
\hline & Yes & $2866 \mathrm{a}$ & & $590 \mathrm{c}$ & $4064 \mathrm{a}$ \\
\hline \multirow[t]{2}{*}{ Alfalfa + Bromegrass } & No & $2579 b$ & & $711 b$ & $4015 \mathrm{a}$ \\
\hline & Yes & $2797 \mathrm{a}$ & & $893 a$ & $4151 \mathrm{a}$ \\
\hline$P$ values & & $<.0001$ & & 0.0027 & $<.0001$ \\
\hline \multirow[t]{3}{*}{ SEM } & & 67.6 & & 29.0 & 95.5 \\
\hline & \multicolumn{5}{|c|}{ Forage Crop $\times$ Cut 1 Date Interaction Effects } \\
\hline & Time & & $\mathrm{ADF}$ & $\mathrm{CP}$ & TDN \\
\hline \multirow[t]{4}{*}{ Alfalfa } & & & $1890 \mathrm{~g}$ & $887 \mathrm{~b}$ & $3011 \mathrm{e}$ \\
\hline & & & $2625 \mathrm{bcd}$ & $1025 \mathrm{a}$ & $3847 \mathrm{~b}$ \\
\hline & & & $2618 \mathrm{~cd}$ & $834 \mathrm{bc}$ & $3911 b$ \\
\hline & & & $2090 \mathrm{fg}$ & $581 \mathrm{e}$ & $3224 \mathrm{de}$ \\
\hline \multirow[t]{4}{*}{ Bromegrass } & & & $2047 \mathrm{~g}$ & $657 \mathrm{de}$ & $2927 \mathrm{e}$ \\
\hline & & & $2326 \mathrm{ef}$ & $616 \mathrm{de}$ & $3426 \mathrm{~cd}$ \\
\hline & & & $2686 b c$ & $372 f$ & $3703 \mathrm{bc}$ \\
\hline & & & $2655 b c$ & $359 f$ & $3885 b$ \\
\hline \multirow[t]{4}{*}{ Alfalfa + Bromegrass } & & & $2371 \mathrm{de}$ & $893 b$ & $3646 \mathrm{bc}$ \\
\hline & & & $2880 \mathrm{ab}$ & $926 \mathrm{ab}$ & $4488 \mathrm{a}$ \\
\hline & & & $2988 \mathrm{a}$ & $723 \mathrm{~cd}$ & $4375 a$ \\
\hline & & & 2513 cde & $665 \mathrm{de}$ & $3824 \mathrm{~b}$ \\
\hline$P$ values & & & 0.0030 & 0.0155 & $<.0001$ \\
\hline SEM & & & 93.4 & 41.0 & 128.0 \\
\hline \multicolumn{6}{|c|}{ Forage Crop Means } \\
\hline Crop & & & $\mathrm{ADF}$ & $\mathrm{CP}$ & $\mathrm{TDN}$ \\
\hline Alfalfa & & & $2306 \mathrm{~b}$ & $832 \mathrm{a}$ & $3498 b$ \\
\hline Bromegrass & & & $2428 b$ & $501 \mathrm{~b}$ & $3485 b$ \\
\hline Alfalfa + Bromegrass & & & $2688 \mathrm{a}$ & $802 \mathrm{a}$ & $4083 a$ \\
\hline$P$ values & & & 0.0011 & $<0.0001$ & 0.0004 \\
\hline SEM & & & 50.1 & 19.9 & 74.0 \\
\hline
\end{tabular}


Continued

\begin{tabular}{|c|c|c|c|}
\hline \multicolumn{4}{|c|}{ Cut 1 Date Means } \\
\hline Cut date & $\mathrm{ADF}$ & $\mathrm{CP}$ & TDN \\
\hline Late June & $2103 d$ & $812 a$ & $3195 c$ \\
\hline Early July & $2610 \mathrm{~b}$ & $856 a$ & $3920 \mathrm{a}$ \\
\hline Late July & $2764 a$ & $643 b$ & $3996 a$ \\
\hline Late August & $2419 c$ & $535 c$ & $3644 \mathrm{~b}$ \\
\hline$P$ values & $<0.0001$ & $<0.0001$ & $<0.0001$ \\
\hline SEM & 54.4 & 23.1 & 79.7 \\
\hline \multicolumn{4}{|c|}{ Fertility Means } \\
\hline Fertility & $\mathrm{ADF}$ & $\mathrm{CP}$ & TDN \\
\hline Unfertilized & $2291 b$ & $650 \mathrm{~b}$ & $3461 b$ \\
\hline Fertilized & $2657 \mathrm{a}$ & $773 a$ & $3917 \mathrm{a}$ \\
\hline$P$ values & $<0.0001$ & $<0.0001$ & $<0.0001$ \\
\hline SEM & 40.1 & 16.3 & 57.8 \\
\hline
\end{tabular}

${ }^{a}$ The same lowercase letters within a column for a particular treatment or interaction effect indicate no significant difference between treatments at $\mathrm{P}=0.05$.

The $\mathrm{CP}$ concentration sequence was alfalfa $>$ alfalfa-bromegrass mixture $>$ bromegrass. But the $\mathrm{CP}$ yield was significantly greater for the alfalfa and alfalfa-bromegrass mixture than bromegrass.

The CP concentration was highest with Late June Cut 1 date and declined with delay in Cut 1 date until Late July, and further delay in Cut 1 had no effect on the CP concentration. The CP yield for the Late June and Early July Cut 1 dates were not significantly different from each other and were higher than both later Cut 1 dates. Also, the Late July date had significantly more CP yield than Late August. Fertilizer application significantly increased both the CP concentration and $\mathrm{CP}$ yield.

\section{Total digestible nutrients (TDN) concentration and yield}

The TDN concentration was not significantly affected by the forage crop $x$ fertility interaction (Table 3). But fertilizer application tremendously improved the TDN yield of bromegrass, while there was only small (not significant) improvement for the alfalfa and alfalfa-bromegrass mixture (Table 4).

The forage crop $\times$ Cut 1 date interaction did not significantly affect the TDN concentration (Table 3), while it did influence the TDN yield (Table 4). The TDN yield from Alfalfa and alfalfa-bromegrass mixture was significantly greater for the Early and Late July Cut 1 treatments than the other two Cut 1 date treatments, but for bromegrass it increased with delay in Cut 1 until Late August.

Bromegrass had lower TDN concentration than the alfalfa and alfalfa-bromegrass mixture (Table 3 ) and alfalfa-bromegrass mixture produced significantly more TDN yield than both the alfalfa and bromegrass (Table 4).

The TDN concentration was significantly lower for the Late July Cut 1 than 
other dates, even though the difference was about $10 \mathrm{~g} \cdot \mathrm{kg}^{-1}$ only (Table 3 ). But the TDN yield was significantly greater from July Cut 1 dates than the earlier or later dates, and it was also greater with the Late August date Cut 1 than Late June Cut 1 date (Table 4). Fertilizer application did not affect the TDN concentration (Table 3), but it significantly increased TDN yield (Table 4).

\section{Acid detergent fiber (ADF) concentration and yield}

Both the forage crop $\times$ fertility and crop $\times$ Cut 1 date interactions were not significant for the ADF concentration (Table 3), but they had significant effect on the ADF yield (Table 4). The ADF yield for bromegrass and alfalfa-bromegrass mixture significantly increased by fertilizer application, but not for alfalfa.

Both Early July and Late July Cut 1 dates produced significantly more ADF yield than the Late June or Late August Cut 1 date for alfalfa and alfalfa-bromegrass mixture (Table 4). But the bromegrass ADF yield was significantly greater for the Late July and Late August Cut 1 dates than the earlier Cut 1 dates.

Bromegrass had higher ADF concentration than both the alfalfa and alfalfa-bromegrass mixture crop types (Table 3 ), and alfalfa-bromegrass mixture had higher ADF yield than both sole crops (Table 4)

The ADF concentration was higher with Late July Cut 1 treatment than the other dates of Cut 1 (Table 3 ), and the ADF yield showed a sequence of Late July $>$ Early July $>$ Late August $>$ Late June (Table 4). Fertilizer application did not have a significant effect on the ADF concentration (Table 3 ), but it significantly increased the ADF yield (Table 4).

\section{Discussion}

In this study, delaying the timing of haying resulted in higher DMY of the Cut 1, which is consistent with a study (Pullman, Washington, USA) by Austenson [15]. If hay of forage grass is being cut only once, delaying haying until later in the growing season would be reasonable consideration to obtain maximum DMY.

However, a delay in harvest may result in a loss of both the protein content and digestibility of the grass and legume hay. Other studies in western Canada have found decline in hay quality with advancing plant maturity [2] [7] [16]. This loss would be most significant for stands consisting of bromegrass alone. Where alfalfa is included in the mix and makes up approximately half of the mixture or where alfalfa is grown alone, the decline in protein and digestibility will not be as great. In a field study in Saskatchewan, Canada, Yu et al. [7] found that as plant maturity advanced, crude protein was reduced in both alfalfa and timothy, and fibre was affected very little in alfalfa but increased in timothy.

As would be expected, fertilizer application tended to improve total yield and quality of forage hay in this study. Other studies have found greater yield increases with the addition of fertilizer [2]. The low response to fertilizer in this study can be contributed to good soil nutrient status and the contribution of fixed $\mathrm{N}$ from the alfalfa in the alfalfa-bromegrass mixture. 
The NRC [17] model predicts that a dry cow in early gestation requires 7 to $8 \% \mathrm{CP}$ in the diet for maintenance, which increases to $11 \%$ to $13 \% \mathrm{CP}$ in young growing or lactating cows. Protein levels in this study for alfalfa usually remained above $11 \%$ for the Late June and Early July treatments only. Bromegrass protein content reached $11 \%$ only with the Late June cut when fertilized.

Seeding a mixture of grass and alfalfa generally resulted in higher forage yields than monoculture alfalfa or bromegrass. Mixtures of a well-adapted grass, and alfalfa have been shown to produce as well as either of the components alone in northeast Saskatchewan, on land where alfalfa is adapted [18]. Malhi et al. [19] found that that seeding alfalfa in mixed stands with bromegrass can generate savings in $\mathrm{N}$ fertilizer, without compromising on the forage yield, forage quality or net earnings.

When producers are considering a two-cut system in northeast Saskatchewan, they should aim to take the first cut in early July and the second cut in late August to maximize yield and provide a good combination of protein and TDN for beef cattle. Under a single cut system, cutting until late July would still be expected to provide a suitable combination of yield and quality of alfalfa and alfalfa bromegrass mixtures for beef cattle.

The late September cutting date of the Cut 2 is recommended in this area of Western Canada to avoid cutting during the critical fall period for alfalfa. However, late September is often a difficult time of the year to dry hay because of the cooler daytime temperature and shorter day length. Producers would need to consider this when adopting these dates for harvesting forage for hay.

Fertilization of newly seeded stands containing alfalfa in the first three production years may not result in a significant increase in DMY when soil nutrient status is adequate [1]. Foster et al. [18] found similar results and concluded that $\mathrm{N}$ fixation was adequate for the crop for the first three production years of alfalfa grass mixtures in a study at Melfort Saskatchewan. In this study, fertilizer had a significant effect on TDN. From a study near Mandan, North Dakota, U.S.A., Berdahl et al. [20] reported application of $50 \mathrm{~kg} \mathrm{~N} \mathrm{ha}^{-1}$ had no effect on in vitro dry matter digestibility or neutral detergent fibre levels of grass or alfalfa, but it did increase crude protein levels in grass monocultures. When bromegrass is seeded alone for hay, soil $\mathrm{N}$ will be depleted quickly, as $\mathrm{N}$ fertilization appears to increase DMY after the first production year.

\section{Conclusion}

With delaying cutting stage for Cut 1 , forage DMY of all three forage crops generally increased for Cut 1, but it decreased for the Cut 2. When Cut 1 and Cut 2 forage yields were added, the highest yielding treatment of all three forage crops was the combination of July 10 and Autumn cuts. Alfalfa-bromegrass mixture yielded higher than alfalfa or bromegrass alone. The $\mathrm{CP}$ concentrations in Cut 1 forage usually declined as the forage crops matured. The $\mathrm{CP}$ concentrations were highest for alfalfa, followed by alfalfa-bromegrass mixture, with the lowest for 
bromegrass. There was little or no effect of crop maturity on the TDN and ADF concentration in forage. The TDN concentrations were higher and ADF concentration was lower in forage from alfalfa or alfalfa-bromegrass mixture than bromegrass. Fertilizer application increased $\mathrm{CP}$ concentration only for alfalfa-bromegrass mixture. Delaying harvesting for Cut 1 increased ADF yield and TDN yield until Late July, but CP yield generally decreased with forage crop maturity. The ADF and TDN yields were higher for alfalfa-bromegrass mixture than bromegrass or alfalfa alone, and CP yield for alfalfa or alfalfa-bromegrass mixture was considerably higher than bromegrass. Fertilization increased $\mathrm{CP}$ yield and ADF yield for bromegrass and alfalfa-bromegrass mixture, and TDN yield only for bromegrass. In summary, forage yield of all three crops generally increased with delaying harvesting for Cut 1 but it decreased for Cut 2. Total DMY (Cut $1+$ Cut 2) was highest for a combination of Early July and Autumn cuts. Forage yield was highest for alfalfa-bromegrass mixture, followed by alfalfa and lowest for bromegrass. The CP and TDN concentrations were higher, and ADF concentration was lower in forage from alfalfa or alfalfa-bromegrass mixture than bromegrass. Fertilizer application increased Cut 1 DMY, total DMY and TDN yield for bromegrass, CP concentration for alfalfa-bromegrass mixture, and $\mathrm{CP}$ and $\mathrm{ADF}$ yield for bromegrass and alfalfa-bromegrass mixture.

\section{Acknowledgements}

The project was supported by the Agricultural Demonstration of Practices and Technologies (ADOPT) initiative under the Canada-Saskatchewan Growing Forward bi-lateral agreement. The project was undertaken by the Northeast Agriculture Research Foundation in Co-operation with the AAFC Melfort Research Farm.

\section{Conflicts of Interest}

The authors declare no conflicts of interest regarding the publication of this paper.

\section{References}

[1] McElgunn, J.D., Heinrichs, D.H. and Ashford, R. (1972) Effects of Initial Harvest Date on Productivity and Persistence of Alfalfa and Bromegrass. Canadian Journal of Plant Science, 52, 801-804. https://doi.org/10.4141/cjps72-130

[2] Malhi, S.S., Foster, A. and Gill, K.S. (2003) Harvest Time and N Fertilizer Effects on Forage Yield and Quality of Quackgrass (Elytrigia repens L.) in Northeastern Saskatchewan. Canadian Journal of Plant Science, 83, 779-784. https://doi.org/10.4141/P02-067

[3] Aasen, A. and Bjorge, M. (2009) Alberta Forage Manual. Alberta Agriculture and Rural Development Publication, Agdex 120/20-1, 348.

[4] Jenson, K.R., Joseph, G., Rigby, C. and Waldron, B. (2017) Comparative Trends in Forage Nutritional Quality across the Growing Season in Thirteen Grasses. Canadian Journal of Plant Science, 97, 72-82. https://doi.org/10.1139/CJPS-2015-0328 
[5] Bonin, S.G. and Tomlin, D.C. (1968) Effects of Nitrogen on Herbage Yields of Timothy Harvested at Various Stages. Canadian Journal of Plant Science, 48, 501-509. https://doi.org/10.4141/cjps68-097

[6] Saskatchewan Forage Production Guide. https://publications.saskatchewan.ca/\#/products/75246

[7] Yu, P., Christensen, D.A., McKinnon, J.J. and Market, J.D. (2003) Effect of Variety and Maturity on Chemical Composition, Carbohydrate and Protein Subfractions, in Vitro Rumen Degradability and Energy Values of Timothy and Alfalfa. Canadian Journal of Animal Science, 83, 279-290. https://doi.org/10.4141/A02-053

[8] Cornell Cooperative Extension (2020) 1st Cutting Forage Quality Update. Central New York Dairy, Livestock and Field Crops, Cornell University, Ithaca.

[9] Loeppky, H.A., Hiltz, M.R., Bittman, S. and Frick, B. (1996) Seasonal Changes in Yield and Nutritional Quality of Cicer Milkvetch and Alfalfa in Northeastern Saskatchewan. Canadian Journal of Plant Science, 76, 441-446. https://doi.org/10.4141/cjps96-078

[10] Norton, N.A., Clark, R.T., Reece, P.E. and Eskridge, K.M. (2013) Quality as a Factor in the Optimal Choice of Fertilizer and Harvest Date of Meadow Hay. Journal of Production Agriculture, 10, 551-556. https://doi.org/10.2134/jpa1997.0551

[11] Association of Official Analytical Chemists (AOAC) (1995) Protein (Crude) in Animal Feed. Combustion Method (990.03). Official Methods of Analysis, 16th Edition, AOAC, Washington DC.

[12] Association of Official Analytical Chemists (AOAC) (1990) Fat (Crude) or Ether Extract in Animal Feed (920.39). Official Methods of Analysis, 15th Edition, AOAC, Washington DC.

[13] NFTA (1993) Neutral Detergent Fiber Determination after Digestion of Samples in Neutral Detergent Solution with Labconco Digestion Unit. Labconco, Kansas City.

[14] SAS Institute Inc. (2004) Online Documentation for SAS, Version 8. Cary. https://support.sas.com/en/documentation.html

[15] Austenson, H.M. (1963) Influence of Time of Harvest on Yield of Dry Matter and Predicted Digestibility of Four Forage Grasses. Agronomy Journal, 2, 149-153. https://doi.org/10.2134/agronj1963.00021962005500020018x

[16] Waldie, O., Wright, S.B. and Cohen, R.D.H. (1983) The Effects of Advancing Maturity on Crude Protein and Digestibility of Meadow Foxtail (Alopecurus pratensis) and Timothy (Phleum pretense). Canadian Journal of Plant Science, 63, 1083-1085. https://doi.org/10.4141/cjps83-139

[17] National Research Council (NRC) (2000) Nutrient Requirements of Beef Cattle. 7th Rev. Edition, The National Academies Press, Washington DC.

[18] Foster, A., Vera, C.L., Malhi, S.S. and Clarke, F.R. (2014) Forage Yield of Simple and Complex Grass-Legume Mixtures under Two Management Strategies. Canadian Journal of Plant Science, 94, 41-50. https://doi.org/10.4141/cjps2013-095

[19] Malhi, S.S., Zentner, R.P. and Heier, K. (2002) Effectiveness of Alfalfa in Reducing Fertilizer N Input for Optimum Forage Yield, Protein Concentration, Returns and Energy Performance of Bromegrass Alfalfa Mixtures. Nutrient Cycling in Agroecosystems, 62, 219-227. https://doi.org/10.1023/A:1021229824357

[20] Berdahl, J.D., Karn, J.F. and Hendrickson, J.R. (2004) Nutritive Quality of Cool-Season Grass Monocultures and Binary Grass-Alfalfa Mixtures at Late Harvest. Agronomy Journal, 96, 951-955. https://doi.org/10.2134/agronj2004.0951 